A Note on Nietzsche's Eternal Recurrence

Neminemus

Author Note

neminemus@,outlook.com 


\begin{abstract}
In contemporary scholarship, it is readily assumed that Nietzsche's Eternal Recurrence either does or does not overcome the 'problem of nihilism'. This exclusive disjunction, however, is false. It has arisen out of the poor exegesis that Eternal Recurrence is meant to overcome nihilism and, if it does not, then this can be considered a shortcoming of Nietzsche's philosophic enterprise. But Eternal Recurrence only overcomes what you want it to: if you do not want to overcome nihilism but embrace it, then Eternal Recurrence does not overcome nihilism, but this is in no way its failure. Keywords: Nietzsche; Eternal Recurrence; Affirmation; Nihilism
\end{abstract}




\section{A Note on Nietzsche's Eternal Recurrence}

A dogmatist came to me and asked of me the question: "Does Nietzsche's Eternal Recurrence help overcome nihilism?" And because the man said unto me that he was a scholar of the Eternal Recurrence and I was sure he wished to laud over me his wisdom of the matter, that he would prove himself the wiser as regards the matter of nihility than I, thus I knew that the man was a dogmatist, that he did not know himself a dogmatist, and that I could not convince the man of his dogmatism. Nevertheless, the fool in my heart could not retain his silence at the affront, and spoke up thus about Eternal Recurrence.

Amongst the academics there is some significant doubt as to whether Eternal Recurrence is cosmological, poetically metaphorical, or hypothetically experimental. ${ }^{1}$ Men find themselves divided into camps over the matter, each with their own fundament in Nietzsche, each with their own exegesis of the philosopher. But amongst them are few that see the similarities in the differences and can divide what is false from what is true, and these men know that Eternal Recurrence is an instrument whose song is heard only by the musician. But these men are few and, that they are seen dancing, they are thought mad by those who cannot hear the music. ${ }^{2}$

Now, with this proper reading, or exegetical simulacra, as with most men who read of Eternal Recurrence, the general consensus amongst the academics seems to be that it provides an antidote to the 'problem of nihilism'. ${ }^{3}$ At least they are undivided on its purpose, if they squabble

${ }^{1}$ For cosmological cf. WTP 35, 36, 55, 1066; Ansell-Pearson, 1994: 112; McNeil, 2020: 30-32, 51 ff.; Loeb, 2009, 2010, 2013. For poetically metaphorical cf. TSZ 269-270; TI 562; Ansell-Pearson, 1994: 110; McNeil, 2020: 39-42. For hypothetically experimental cf. GS 335, 341; WTP 46; Ansell-Pearson, 1994: 112; McNeil, 2020: 24-30; Clark, 1990; Soll, 1973.

${ }^{2}$ An idiom. Attributed i.a. to Staël-Holstein, 1814: 275; Prime, 1848: 143; Spofford, 1860: 279; Barr, 1885: 95; Bergson, 1911: 5.

${ }^{3}$ McNeil, 2020: 19-24. 
about its form. But, just as many know not that it is an instrument, there are few that know that Eternal Recurrence does not necessarily overcome nihilism, that it cannot, and that it is not meant to. Their false reasoning presupposes a certain credence of the musician, that they want to overcome nihilism; but such valuism - the term is invented out of a disbelief in the contradistinction between existentialism and nihilism - is not to be found anywhere upon the face of the world, nor in the essence of men. Rather, as with any tool, the consequent is conditional upon the antecedent: to wit, what Eternal Recurrence does is contingent upon what you want it to do.

The antecedents to Eternal Recurrence are an ideal and a lived reality. The instrument necessitates an existential introspection viz. whether the ideal is realised in the lived reality. Say one should leap up and say: "In this single moment of affirmation all eternity was called good, redeemed, justified, and affirmed."4 $\mathrm{He}$ is a 'Yes-sayer', 5 that he 'wants nothing to be different, not forward, not backward, not in all eternity': ${ }^{6}$ He has amor fati. But say that one should throw themself down and gnash their teeth, ${ }^{7}$ saying: "Forsooth! That this here were my past and my future, a never ending present; I should tear my eyes from my head, that I would escape this fate." He has not amor fati.

Now, we should consider the latter man, since overcoming involves a certain absence or unwant which seeks to be surmounted, and only our latter man finds something to be overcome to wit, his hatred of fate. Say that the ideal of the latter man were valuistic. Perhaps he sees objective value in a God-fearing life. Eternal Recurrence necessitates the cross examination of the

\footnotetext{
${ }^{4}$ WTP 1032.

${ }^{5}$ GS 276.

${ }^{6}$ EH, 'Why I Am So Clever', 10.

${ }^{7}$ GS 341 .
} 
past and present moment, and our man is not a Yes-sayer, because he finds a problem with the lived reality; too much time spent at bookies and brothels leaves his reality detached from his desirous ideal. Or perhaps he is not a Yes-sayer because he finds fault with the ideal; just enough time spent in bookies and brothels leaves his ideal detached from his desirous reality. Either way, he does not love his fate because its reality does not match its ideal. What if he were nihilistic? Perhaps he idealises reconciliation with the Absurd. Again, our man is not a Yes-sayer, because he finds that he has been living in spite of the Absurd instead, because his reality does not match his ideal. Affirmation is enformed by the ideals that seek to be affirmed.

Tell me, is there any difference between the two? Both men have within themselves an existential ideal, and both men are living things with a lived reality, which may or may not reflect those ideals. Each takes up the instrument and each finds thereupon that their ideal is not to be found in their world. The content of their ideals is beside the point. To say that Eternal Recurrence overcomes nihilism is to presuppose a valuistic ideal, one which precludes a nihilistic one. If one does not want to preclude nihilism, but rather embrace it, then Eternal Recurrence would equally serve to overcome valuism.

Now you may ask of me whether Eternal Recurrence has such power, that it can overcome; and you may say to me that you do not understand the instrument - so let me say something of its mechanism. Eternal Recurrence is didactic in two familiar ways. As any other question, one's answer will be enformed by their ideals. So what makes Eternal Recurrence a tool more than merely a question? Firstly, the question itself demands an evaluation of one's living, on the back of which revaluation takes place. And secondly, the answer to the question demands a revaluation of one's living in the event that they are a No-sayer. Just as a mere question 'Where is the Good in 
God?' asks for a mere recitation of one's ideals, so another question 'Why do you need a Devil when you have a God like this?' asks for an affirmation of one's ideals.

But just as some questions have this greater provocative power, so do others have a power greater yet: namely, that by which revaluation as a consequence of the question is enformed by the question: to wit, inherent in the question is an ideal, and revaluation is prompted to take on this ideal in stead of that which was emptied by the question. The question causes the necessary to nihilate the ideal because the necessary gains the weight of infinitude - 'the greatest weight' ${ }^{8}$ One cannot bear the necessary for the sake of some ideal, but must come to love the necessary for itself, and then shape their ideals after it. This is what Nietzsche means when he says that 'all idealism is mendacity in the face of what is necessary'. ${ }^{9}$ The ideal is lost in the question and another cannot be assumed in the face of necessity. What is left, then, of the antecedent? None other than the lived reality. The question becomes then 'Why do you not love your lived reality?' which can no longer be answered with 'because it does not meet the ideal', because there is no ideal, but must be answered with 'because you have been living for an ideal, rather than for that reality'. So, when only the reality remains, there is nothing left for you, because you put nothing into the face of the world, and everything into a mythical ideal.

In this same reasoning, the same breath of the question, there is an Either/Or. On the one hand, one can seek to make the necessary rather than the ideal the object of their affection; amor fati ipsissima verba - the love of fate by virtue of loving what fate $i s$, to wit, the necessary. On the other hand, one can abandon love, and seek out a perfectly perpetual ataraxy. ${ }^{10}$ The former will

${ }^{8}$ GS 341.

${ }^{9} \mathrm{EH}$, 'Why I Am So Clever', 10.

${ }^{10}$ Is there a third option? That one can deny the question, and seek to reconcile the necessary with the ideal? That one should wander in the desert for all their lives, searching for love in an irreal object of 
win for himself 'a will to live without rejecting anything of life', ${ }^{11}$ 'to exclude nothing and to learn how to braid with white thread and black thread a single cord stretched to the breaking-point' ${ }^{12}$ He will find the Courage to Be. ${ }^{13}$ He can 'imagine Sisyphus happy'. ${ }^{14}$ The latter wins for himself the same end, only there is no zeal for him; a 'belief in unbelief'. ${ }^{15}$ Regardless, for both Ways, there is only the necessary, there is no ideal. And this is how Nietzsche's ideal - 'to see as beautiful what is necessary in things ${ }^{36}$ - enforms revaluation in the face of his question.

But alas, you surely want to know of the Ways which is the best. The Way of Love demands of a man that he take unto himself the Absurd, only to refute it, ${ }^{17}$ for the Absurd is a loveless thing, yet 'one must still have chaos in oneself in order to give birth to a dancing star' ${ }^{18}$ But then, I should ask of you, is your soul so strong as to bear this 'demoniac madness'? ${ }^{19}$ The Way of Nothing is best suited for dead men, for the living too weak for ataraxy find hatred in its place. What will you do, you knight of faith, when you discover that the Absurd is not impartial, nor partial towards you? Is your principle so powerful as to escape existence through philosophical suicide? So tell me thus, does either Way seem good to you?

So I said unto the dogmatist that Eternal Recurrence does overcome - it is a potent tool. As for what it overcomes, that is contingent upon who wields the tool, to some extent, but also

love? But, is this really any different from the latter, but for the fact that they have failed to achieve ataraxy, garnering in its place a hatred of the necessary?

${ }^{11}$ Camus, 2013: 150.

${ }^{12}$ Camus, 2013: 150.

${ }^{13} \mathrm{cf}$. Tillich, The Courage to Be.

${ }^{14}$ Camus, 2013: 89.

${ }^{15}$ GS 347.

${ }^{16}$ GS 276.

${ }^{17} \mathrm{cf}$. Camus, The Myth of Sisyphus.

18 TSZ, 'Zarathustra's Prologue', 5.

${ }^{19}$ Kierkegaard, 1983: Part I, Chapter 3. 
Nietzschean philosophy, to another extent. This is why Nietzsche, 'the teacher of the eternal recurrence', ${ }^{20}$ thought it the highest achievement of all his philosophy; ${ }^{21}$ because it epitomized everything he believed in: 'It is not enough to prove something, one has to seduce or elevate people to it'.22

\footnotetext{
${ }^{20} \mathrm{TI}$, 'What I Owe to the Ancients', 5.

${ }^{21}$ McNeil, 2020: 22. cf. Ansell-Pearson, 1994: 238.

${ }^{22}$ D 330
} 


\section{Bibliography}

Ansell-Pearson, K. (1994). An Introduction to Nietzsche as Political Thinker. The Perfect Nihilist. Cambridge: Cambridge University Press.

Barr, A. E. (1885). The Hallam Succession: A Tale of Methodist Life in Two Countries. London: Phillips \& Hunt.

Bergson, H. (1911). Laughter: An Essay on the Meaning of the Comic. (Brereton, C.; Rothwell, F., Trans.) New York: The Macmillan Company.

Camus, A. (2013). Return to Tipasa. In The Myth of Sisyphus (O'Brien, J., Trans., pp. 143-152). London: Penguin Classics.

Camus, A. (2013). The Myth of Sisyphus. (O'Brien, J., Trans.) London: Penguin Classics.

Clark, M. (1990). Nietzsche on Truth and Philosophy. Cambridge: Cambridge University Press.

Kierkegaard, S. (1983). The Sickness Unto Death. (Hong, H. V.; Hong, E. H., Eds. \& Trans.) Princeton: Princeton University Press.

Loeb, P. S. (2009). Identity and Eternal Recurrence. In Ansell-Pearson, K. (Ed.), A Companion to Nietzsche (pp. 171-188). Chichester: Wiley-Blackwell.

Loeb, P. S. (2010). The Death of Nietzsche’s Zarathustra. Cambridge: Cambridge University Press.

Loeb, P. S. (2013). Eternal Recurrence. In Gemes, K.; Richardson, J. (Eds.), The Oxford Handbook of Nietzsche (pp. 645-671). Oxford: Oxford University Press.

McNeil, B. E. (2020). Nietzsche and Eternal Recurrence. London: Palgrave Macmillan.

Nietzsche, F. (1968). The Will to Power. (Kaufmann, W., Trans.) New York: Vintage Books.

Nietzsche, F. (1974). The Gay Science: with a Prelude in Rhymes and an Appendix of Songs. (Kaufmann, W., Trans.) New York: Random House.

Nietzsche, F. (1997). Daybreak: Thoughts on the Prejudices of Morality. (Hollingdale, R. J., Trans.) Cambridge: Cambridge University Press.

Nietzsche, F. (2008). Thus Spoke Zarathustra. (Parkes, G., Trans.) Oxford: Oxford University Press.

Nietzsche, F. (2009). Ecce Homo. (Large, D., Trans.) Oxford: Oxford University Press.

Nietzsche, F. (2009). Twilight of the Idols, or, How to philosophize with a hammer. (Large, D., Trans.) Oxford: Oxford University Press. 
Prime, W. C. (1848). The Owl Creek Letters, And Other Correspondence. New York: Baker \& Scribner.

Simmel, G. (1991). Schopenhauer and Nietzsche. (Loiskandl, H.; Weinstein, D.; Weinstein, M., Trans.) Urbana and Chicago: University of Illinois Press.

Soll, I. (1973). Reflections on Recurrence: A Re-examination of Nietzsche's Doctrine, die Ewige Wiederkehr des Gleichen. In Solomon, R. C. (Ed.), Nietzsche. A Collection of Critical Essays (pp. 339-342). New York: Anchor Press/Doubleday.

Spofford, H. E. P. (1860). Sir Rohan's Ghost. London: Trübner \& Co.

Staël-Holstein, A.L.G. de. (1814). Moravian Modes of Worship. In Germany (Vol. II, pp. 275-278). New York: Eastburn, Kirk and Co.

Tillich, P. (2000). The Courage to Be. New Haven: Yale University Press. 